\title{
Corporate social responsibility in global and local companies of Southeast Europe
}

\author{
Article history: \\ Received: 24 November 2015 \\ Sent for revision: 6 December 2015 \\ Received in revised form: 31 January 2017 \\ Accepted: 1 February 2017 \\ Available online: 5 April 2017
}

\begin{abstract}
The aim of this work is the analysis of theoretical assumptions and empirical research to find the answer to the question on how the activities in the field of corporate social responsibility in the region of Southeast Europe are present in the business of global and local companies market. Whether and to what extent to implement socially responsible behavior of companies with a different ownership structure, the revenue volume, market share, market activities and markets where it operates, and if the objectives of the companies are in line with the goals of social communities. they offer other than legal, and more benefits for their employees and provide them extra protection, whether, and to what extent, the state helps in carrying out socially useful activities and the compliance of the company's positive legal norms and international standards? The result of the research offered the conclusion that social responsibility activities in companies market of SE Europe are present in an increasing scope, a CSR program contributes to the awareness of the importance and necessity of such activities in the construction of a positive corporate image and relations of the companies with communities and stakeholders in the region.
\end{abstract}

Keywords: Corporate social responsibility, social responsibility of enterprise, and socially responsible activities

\section{Korporativna društvena odgovornost kod globalnih $\mathbf{i}$ lokalnih kompanija u jugoistočnoj Evropi}

Apstrakt: Cilj ovog rada jeste kroz analizu teorijskih postavki te empirijskog istraživanja doći do odgovora na pitanja koliko su aktivnosti iz domena

\footnotetext{
${ }^{1}$ NITES BiH, fuad.cibukcic@nites.eu 
Čibukčić F.: The model for improving the manufacturing process in Serbian...

društvene odgovornosti kompanija u regiji jugoistočne Evrope prisutni $u$ poslovanju globalnih i lokalnih kompanija tog tržišta. Da li, i u kojoj mjeri se društveno odgovorno ponašanje implementira kod kompanija s različitom vlasničkom strukturom, prihodovnom obimu, tržišnom udjelu, tržišnim aktivnostima te tržištima na kojim posluju te jesu li ciljevi kompanije usklađeni $s$ ciljevima društvenih zajednica. Empirijsko istraživanje provedeno kod najvećih globalnih i lokalnih kompanija u BiH, Hrvatskoj i Srbiji koje ukupno upošljavaju preko 63,000 ljudi bilo je fokusirano na pitanja da li kompanije posvećuju dužnu pažnju prezervaciji životne i radne okoline, da li i u kojoj mjeri podržavaju zahtjeve društvene zajednice, nude li, osim zakonskih, $i$ dodatne pogodnosti za svoje zaposlenike i obezbjeđuju im dodatnu zaštitu, da li, i u kojoj meri, država pomaže u provođenju društveno korisnih aktivnosti te poštuju li kompanije pozitivne zakonske norme $i$ međunarodne standarde? Rezultat istraživanja ponudio je zaključak kako su društveno odgovorne aktivnosti kod kompanijana tržištu Jl Evrope prisutne u sve većem obimu, a program CSR pridonosi svijesti o važnosti $i$ potrebi ovakvih aktivnosti $u$ izgradnji pozitivnog korporativnog imidža $i$ odnosa tih kompanija sa društvenim zajednicama i interesnim grupama u okruženju.

Ključne reči: Korporativna društvena odgovornost, društveno odgovorno poslovanje.

\section{Introduction}

Corporate social responsibility in the modern economy is the business philosophy, from the end of the last century, and the standard business within the legal framework of modern Western economies. The main goal of CSR is to introduce a co- interesting relationship between the previously mentioned primary interest to make a profit, scarcity of natural resources and growing demands for labor and frequent occurrences of exploitation.

Skeptics of socially responsible companies have opinion that the role of successful companies is to make a profit, not to save the planet, and that stands as a fact from the legal and economic aspect, but the profit and respect for the law must not be the only obligations of modern companies. In a market race, some of the basic facts are often being forgotten. Few of them are the uncontrolled use of the environment and those types of resources, the fact that labor is often used to the boundary where the basic fundamental human rights are being crossed. Also, the companies as same as the owners of capital are forgetting their debt, and it is an obligation which states that a part of realized capital and profits must be returned as part of the reinvestment of the resources that are used as the basic levers to achieve profit targets. 
Čibukčić F.: The model for improving the manufacturing process in Serbian...

Philip Kotler, the father of modern economics, in his book "Corporate Social Responsibility - Doing the most good job for your company and your cause" (Kotler,2005)writes:

If you exercise every day, you will look better, feel better and at the end, you will live longer. A similar benefit will have all the companies that decide to participate in social responsibility. Companies will look better to their potential customers, investors, the media. Their employees, owners, board members will feel better, and many argue that companies with a good reputation in social responsibility survives longer on the market.

Similarly, today's understanding of corporate social responsibility assumes that is managed in a strategic way (Kakabadse, 2007.) Corporate social responsibility has won the war for (Visser, Matten, Pohl, 2010) the ideas, even skeptical research on CSR, published in "The Economist", January 2005, confirmed this view. Since this idea was launched and lives longer than 50 years, especially during the last 15 years has received a huge success and the realization of the economy.

Corporate social responsibility has developed its own language, tools for action, advocates, shared roles, and it is present in the strategies and practices in all industries of the world. After the fall of the Iron Curtain and the progress of globalization, has become a real business, stronger than the individual national governments and their impact, has become a reliable and unavoidable partner, globally as a response to increasingly growing social demands in the world.

\section{Literature review}

Hopkin's corporative social responsibility is clearly defined as "the attention to treat interest-influential groups (stakeholders) that are located outside, but within the organization too in ethical and socially responsible way." The purpose of the social responsibility is to keep the profitability and at the same time to keep the high life standards for interest-influential group inside and outside the enterprise (Hopkins, 2006. Str.299.). The growth of power companies in the markets, also created a need for a discussion on how important role the corporations play in a development of the society and how do they affect the environment .

According to the father of modern marketing, Philip Kotler (Kotler, Lee, 2005), the phrase Corporate Social Responsibility is defined as a commitment to improving the well-being of the community through discretionary business practices and contributions to the betterment of the individual or the community at the expense of resource corporations 
Čibukčić F.: The model for improving the manufacturing process in Serbian...

With the appearance of this question, the interest of a wider public has come out due to the transparency of enterprises business and their responsibility to society, from which those same companies in a great amount depend on. The European Commission defines CSR as "the responsibility of enterprises for the impact on society" and encourages companies to "voluntarily integrate issues of social problems, environmental protection, human rights and consumer issues in their business and business strategy, all in collaboration with their stakeholders", whereby the stakeholders is think of as entities that are associated with the company.

"Corporate social responsibility includes economic, legal, ethical and discretionary (philanthropic) society's expectations of the organization at a given time." This definition is given, in 1979, Dr. Archie B. Carroll, a professor at the University of the Georgia, who has formed a CSR pyramid:

Figure 1. CSR pyramide:

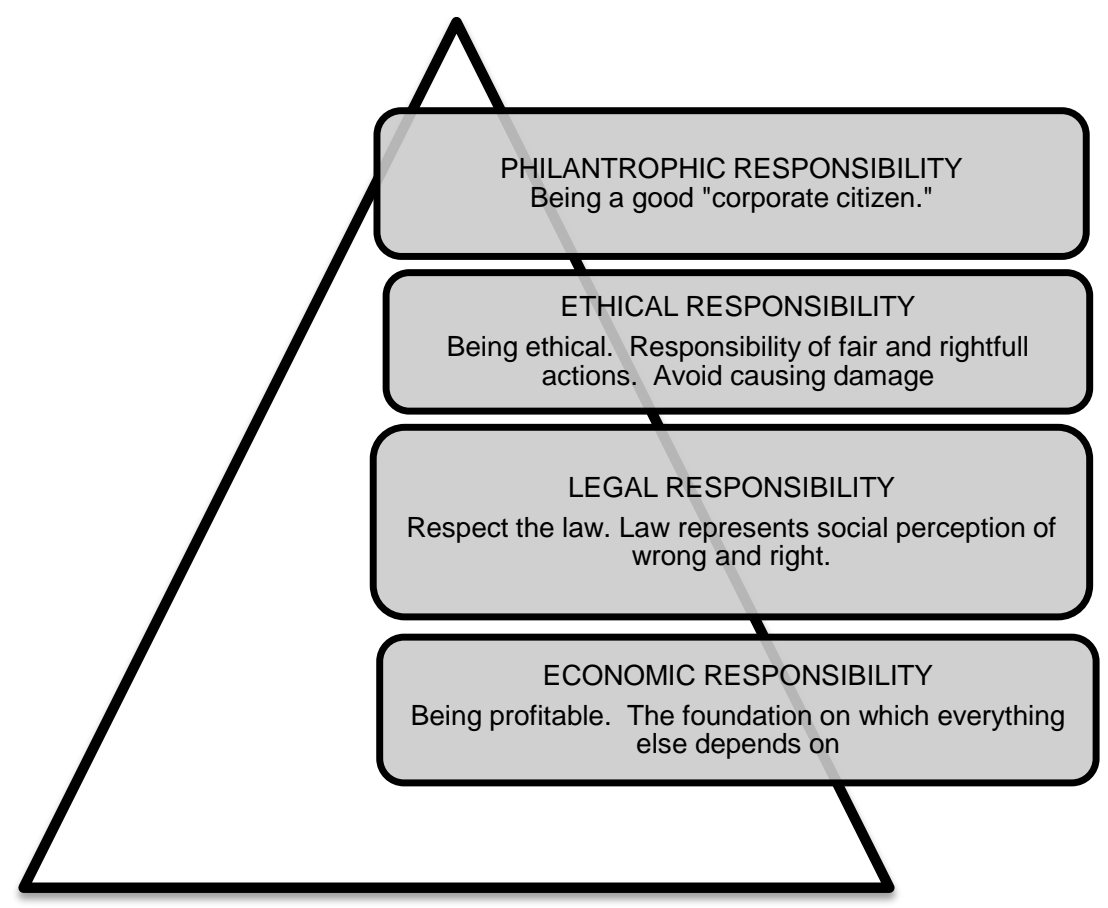

Source: Caroll, Archie, 1996. 
Čibukčić F.: The model for improving the manufacturing process in Serbian...

\section{Research methodology and data}

Through the analysis of the available scientific studies in the field of economic science, and the synthesis of the results of research the mentioned sample of companies in the region of Southeast Europe, investigated the degree of presence, development and implementation of various models of companies' activities in the field of social responsibility. Also, the study deals with the ways by which the daily processes carried out CSR and whether this business philosophy is still just privilege of companies located in free markets in the Western Hemisphere or is part of the business with local, international and global companies in this part of Europe. Research involving different models of active living CSR in companies, comparing the same business with companies operating within the European Union and countries outside the EU. Most attention was dedicated is a large, international and multinational companies, which by themselves in the economic environment play a major role and in which we investigated, among all other things:

- Do companies pay appropriate attention to the preservation of the living and working environment,

- Whether and to what extent they support the demands of the community,

- Do except for legal, offer additional benefits to their employees and provide them extra protection,

- Whether and to which extent, the state helps in carrying out socially useful activities,

- Do companies respect the positive legal norms and international standards

During 2014 and 2015 in Bosnia, Croatia and Serbia as part of a doctoral dissertation (Čibukčić, CSR at global and local companies of SE Europe, 2015) conducted empirical research on a sample of 45 global and local companies employing over 63,000 employees and generate total revenue of more than EUR 3.2 billion. Based on defined goals, a plan and the case studies in this paper have been set following hypotheses:

\section{Hypothesis}

Corporate social responsibility at the global and local companies in Bosnia and Herzegovina, Croatia and Serbia is present in large scale, and the program of CSR contributes to the awareness of the importance and necessity of such activities in the construction of a positive corporate image and relations of the company with communities and stakeholders in the environment. 
Čibukčić F.: The model for improving the manufacturing process in Serbian...

\section{Hypothesis II:}

Corporate social responsibility is designed by a plan, supported the budget and implemented through guided activities at global companies present in the markets of Bosnia and Herzegovina, Croatian and Serbian, while this is not the case for local companies the same size in the same market.

Looking separately, in the market of Bosnia and Herzegovina asked the 10,932 workers employed in some of the largest local and global companies like; BHT Telecom, Coca-Cola, Microsoft, Cisco Systems, VGT Insurance, Avaz Roto Press, Bosnalijek, Sparkasse ... Croatian market in the focus of that research found the 28,449 workers employed in some of the largest companies such as Croatian Telecom, Pliva, INA, JGL Atlantic Group, Hypo Alpe Adria Bank .... In the market of the Republic of Serbia in focus that research found the 23,866 workers employed in some of the largest companies such as Telekom Serbia, Telenor, Delta Holding, MK Group, Coca Cola, Philip Morris, Deloitte, the Atlantic Group.

\section{Research results and discussion}

The companies involved in the research for their activities were very diversified, which is a good fortune for researchers because such a sample is representativeness that we have in the market economies of the countries in which the research was conducted. The results have shown that some of the companies have more activities, while a number of companies come out of the proposed framework of the ten most common activities. Among the most common categories that were offered, there were companies with portfolio connect to information technology and publishing. Observed by sectors, researched companies accounted for:

Table 1. Companies by activities

\begin{tabular}{|c|c|c|c|}
\hline Finance & 33,3 & 33,3 & 33,3 \\
Energetics & 11,1 & 11,1 & 44,4 \\
Trade & 11,1 & 11,1 & 55,6 \\
Telecommunications & 11,1 & 11,1 & 66,7 \\
Building-trade & 11,1 & 11,1 & 77,8 \\
Others (IT, Publishing, & 22,2 & 22,2 & 100,0 \\
etc.). & 100,0 & 100,0 & \\
total &
\end{tabular}

Source: The authors calculation 
Čibukčić F.: The model for improving the manufacturing process in Serbian...

The first question was about the ownership structure of the companies involved in the research. The results indicate that a large majority are privately owned, while only a small percentage are in the partially or fully state-owned. The state in Bosnia and Serbia has maintained the ownership structure in the telecom operators. While in Croatia, only one of the banks operating in this market, Hypo Alpe Adria Bank is owned by the Republic of Austria.

Table 2. The ownerships structure in $\mathrm{BiH}$

\begin{tabular}{|l|c|c||c|}
\hline & Frequency & Percentage & Total percentage \\
\hline Majority private & 9 & 90,0 & 90,0 \\
Majority state & 1 & 10,0 & 100,0 \\
Total & 10 & 100,0 & \\
\hline
\end{tabular}

Source: Authors calculation

Table 3. Ownership structure of Serbia

\begin{tabular}{|l|c|c|c|}
\hline & Frequency & Percentage & Total percentage \\
\hline Majority private & 12 & 92,3 & 92,3 \\
Majority state & 1 & 7,7 & 100,0 \\
Total & 13 & 100,0 & \\
\hline
\end{tabular}

Source; Author's research

Table 4. Ownership structure of Croatia

\begin{tabular}{|l|c|c|c|}
\hline & Frequency & Percentage & Total percentage \\
\hline Majority private & 8 & 88,9 & 88,9 \\
Majority state & 1 & 11,1 & 100,0 \\
Total & 9 & 100,0 & \\
\hline
\end{tabular}

Source; Author's research

For easier nomenclature, the companies included in the study were categorized into those that employ up to 100 workers, those up to 200, companies of 400 employees and those over 500 employees. The results indicate that the investigation mostly covered companies with many employees, more than 500 or $62,5 \%$ of the surveyed companies, while the other three categories represented by the percentage of $12.5 \%$. Looking at the results by countries, it is interesting that $89 \%$ of the companies surveyed in Croatia belonged to the category of employers who employ more than 500 workers. 
Čibukčić F.: The model for improving the manufacturing process in Serbian...

The largest number of workers employed by Telekom Serbia, 9088, followed by INA, Croatia, 8150 , followed by Delta Holding from 6000 , Croatian Telecom 5340, Atlantic Group from 5152, Bosnian Prevent Invest with 5,000 workers, and so on. This question proved to be very useful because the success of the implementation of the activities of CSR leading in the correlation with the size of companies by the number of employees and total turnover.

Tabela 5. Number of employees BiH, Hrvatska i Srbija

\begin{tabular}{|l|c|c|c|}
\hline \multicolumn{1}{|c|}{ Name } & Frequency & Percentage & Total percenatge \\
\hline Up to 100 & 4 & 12,5 & 12,5 \\
to 200 & 4 & 12,5 & 25,0 \\
to 500 & 4 & 12,5 & 37,5 \\
Over 500 & 20 & 62,5 & 100,0 \\
Total & 32 & 100,0 & \\
\hline
\end{tabular}

Source: Author's research

The question that is very important because it determines the basic parameters in the study, is the type of companies by founding capital and market presence. The main and auxiliary hypotheses in their projections were based on this basic premise. Collectively, in the focus of research almost the same percentage of the local and regional were represented in comparison to those international and global companies.

Table 6. Type of company by the presence in the market (Collectively) Bosnia and Herzegovina, Croatia, Serbia

\begin{tabular}{|l|c|c|c|}
\hline \multicolumn{1}{|c|}{ Name } & Frequency & Percentage & Total percentage \\
\hline local & 10 & 31,3 & 31,3 \\
regional & 5 & 15,6 & 46,9 \\
international & 7 & 21,9 & 68,8 \\
globa & 10 & 31,3 & 100,0 \\
Total & 32 & 100,0 & \\
\hline
\end{tabular}

Source: Author's research

According to the results, in the amount of $100 \%$ of the companies surveyed in Croatia, local (regional) and (International) has developed a global strategy relating to social responsibility. Comparing the results with other countries in the region, only $3.1 \%$ of companies in Serbia gave an answer that does not 
Čibukčić F.: The model for improving the manufacturing process in Serbian...

have a strategy CSR. However, the availability of the above mentioned strategies Croatian public is not always present.

Table 7. Availability of public strategy

\begin{tabular}{|l|c|c|}
\hline \multicolumn{1}{|c|}{ Name } & Percentage & Total percentage \\
\hline yes & 66,7 & 66,7 \\
no & 33,3 & 100,0 \\
Total & 100,0 & \\
\hline
\end{tabular}

Source: Author's research

Very important question in this study was related to the crucial element on implementation of CSR strategies in companies, budget. According to the results, most companies pleaded that the total budget is allocated $2 \%$ directed towards CSR. Expounding this a summary of on data by country, it is obvious that in $\mathrm{BiH} 60 \%$ of the company allocates a budget of $2 \%$ and only Avaz Roto Press, Sarajevo, allocates $10 \%$ of total company revenue. In Serbia, something more dispersion of the budget allocation. Over $30 \%$ of companies registered in the Republic of Serbia sets aside $2 \%$ of their income, they provide over $15 \%$ between $2-5 \%$ and almost the same number of those who stand between $5-7 \%$ and $7-10 \%$ for CSR. In company with the registration activities of on Croatian territory, similar to Bosnia and Herzegovina, companies most often choose to $2 \%$ of its revenue purposes the activities in the field of social responsibility, while $11 \%$ of them opted for the budgets in the range of $2-5 \%$.

Table 8. The budget of CSR (collectively) BiH, Croatia, Serbia

\begin{tabular}{|c|c|c|c|c|}
\hline Name & Frequency & Percentage & Percentage & $\begin{array}{c}\text { Total } \\
\text { percentage }\end{array}$ \\
\hline Up to 2\% & 12 & 37,5 & 66,7 & 66,7 \\
from2\% to 5\% & 3 & 9,4 & 16,7 & 83,3 \\
from 5\% to 7\% & 2 & 6,3 & 11,1 & 94,4 \\
from7\% to 10\% & 1 & 3,1 & 5,6 & 100,0 \\
Total & 18 & 56,3 & 100,0 & \\
Ad-hoc budget & 14 & 43,8 & & \\
Total & 32 & 100,0 & & \\
\hline
\end{tabular}

In order to obtain more information on the activities of companies in the field of social responsibility operating in the South East European countries, respondents were asked the question whether they attach their report on CSR activities in its annual report. Answers in collective review suggest that more 
Čibukčić F.: The model for improving the manufacturing process in Serbian...

than $65 \%$ of the company gives special attention to CSR activities in their annual reports. In Bosnia and Herzegovina, almost two-thirds of the company in its annual report has a section on CSR activities, namely $70 \%$, in Croatia the percentage is almost the same, or $66.7 \%$, while in the Republic of Serbia that is somewhat smaller percentage, $61.5 \%$. From this we can conclude that the company pays the needed attention to the reporting of its employees, the public, shareholders, suppliers, the community and the competition on its activities in the field of social responsibility.

Table 9. The report on CSR activities (Collectively) Bosnia and Herzegovina, Croatia, Serbia

\begin{tabular}{|c|c|c|c|c|}
\hline Name & Frequency & Percentage & Percentage & total percentage \\
\hline yes & 21 & 65,6 & 67,7 & 67,7 \\
no & 10 & 31,3 & 32,3 & 100,0 \\
Total & 31 & 96,9 & 100,0 & \\
\hline
\end{tabular}

In terms of standards compliance of companies with local labor laws and international conventions that regulate this issue, almost $100 \%$ of companies in Croatia declared themselves affirmative answer. Refining data by countries in the region, it can be seen as a company registered in the territory of Bosnia and Herzegovina, only a small percentage are lagging behind in companies registered in the Croatian and Serbian, where subjects with perfect proportion declared that they are fully harmonized their corporate statutes with local laws work and international documents in this field.

Half the companies in Croatia declared that the CSR activities integrated in the QM or ISO standards and more than $70 \%$ of companies based to their socially responsible behavior have woven some of the international initiatives relating to CSR (UN Global Compact, the EU, ..) This percentage of the companies in Bosnia and Herzegovina and Croatia is somewhat more modest, $55 \%$, or $63 \%$,

Like the previous question related to social status and rights of workers, companies are, according to the results of this research, have adopted high international and European standards related to this issue. In fact, in average for the whole region of South Eastern Europe, $93.8 \%$ of companies stated that in addition to the guaranteed rights of enterprises and is willing to provide rights for their employees such as additional health insurance, paid maternity leave (the full amount), special examinations for workers exposed to certain radiation, fumes harmful gases or in any other way are exposed to conditions in the workplace that could damage their health.

Looking at separate countries, we can see how companies in the Republic of Serbia and the Republic of Croatia in the amount hundred percent for workers 
Čibukčić F.: The model for improving the manufacturing process in Serbian...

and additional rights and protection while in Bosnia and Herzegovina, the percentage is $88,9 \%$.

Does the company's management regularly maintain contacts with representatives of works councils or trade unions and respects reasonable requests, it was one of the questions that companies in SE Europe almost unanimously answered positively. It is interesting to notice that the company, regardless of legal obligations, in all three countries pay special attention to the legal and voluntary obligations towards their employees, which is certainly an interesting sociological phenomenon. Companies in Croatia fully adapt its plans CSR activities towards the needs of the communities in which they operate. Slightly smaller companies in Serbia and Bosnia and Herzegovina are the same.

Tabela.10. The willingness of companies to adapt their plans to the community in Croatia

\begin{tabular}{|cc|c|c|}
\hline \multicolumn{2}{|c|}{ Name } & Percentage & Total percentage \\
\hline Valid & yes & 77,8 & 77,8 \\
& No & 22,2 & 100,0 \\
& Total & 100,0 & \\
\hline
\end{tabular}

Source: Author's research

In relation to the willingness of companies to adapt their plans towards community in which they do business, companies do not always prepare their plans based on the analysis. Thus, in addition $67.6 \%$ of the companies are investigating the needs of their communities and adapt their CSR plans against them. Refined results by country look like this; Bosnia and Herzegovina, $87.5 \%$, Croatia, $77.8 \%$, and Serbia, $69.2 \%$. Two-thirds of the companies surveyed claimed to invest their own resources in environmental protection as part of its CSR activities. The highest percentage of the companies registered at the Croatian territory, as much as $100 \%$, and lowest in companies in Serbia, only $61.5 \%$. Finally, on the issue of state participation in socially responsible actions, only $44.4 \%$ of the companies surveyed stated that they have support from the government for their activities in the field of social responsibility in the region of SE Europe.

\section{Concluding remarks}

Based on research and analysis of the theoretical assumptions set out in this paper, and synthesis of empirical research, it is justifable to conclude that corporate social responsibility at global and local companies in Bosnia and 
Čibukčić F.: The model for improving the manufacturing process in Serbian...

Herzegovina, Croatia and Serbia is present in an increasing extent, a CSR program contributes to awareness of the importance and need for such activities in construction of a positive corporate image and relations of the company with communities and stakeholders in the region.

To be socially responsible, for modern, market-oriented companies, both the world and the markets covered by this study, it means to be a desirable partner, both for employees and for those who want to become part of the team of the company. That means being a good neighbor to people in social community in which these companies operate, to be "big brother" to individuals and organizations to finance their projects do not have sufficient resources, an attractive partner for those who care about the environment and sustainability of production.

At the same time it means a great commitment to maintain such a reputation, but it also means that these companies have provided high rating in the markets, the customers are a desirable and reliable partner to suppliers and implementers of projects as subcontractors must respect such standards, but ultimately the products, services or solutions of these companies are high on the list of preferred customers, and that means a stable business and a positive balance.For all of this, it can be concluded, that the companies in the market of SE Europe are aware.

From creating a strategy, setting relational plans, budgeting, hiring professionals for conducting such projects and to communicate them with interested stakeholders, processes in companies operating in markets in Bosnia and Herzegovina, Croatia and Serbia are equally valid as the companies on the markets of the Western Hemisphere .

At the beginning of this paper it was pointed out that the CSR should not be seen as a structural right paradigm that those companies with the strategy implemented, CSR will be more successful than those that are not socially responsible. Certainly CSR is not universal pill that solves all the pain of companies in the world market economy of the XXI century, but certainly contributes to their overall health.

At this point we can say that a social responsibility of companies is becoming a business imperative and thus management increasingly understands that it is very important for business, and that exactly as marketing, CSR is actually investment in business. The management increasingly requires to lead companies in a socially responsible way, so that it does not represent the only economic objectives of the company which is headed by objectives of the community as a whole.

Corporate social responsibility in the world is an evolutionary process started almost a century ago, adopted as a dogma and practice of the sixties and it is 
Čibukčić F.: The model for improving the manufacturing process in Serbian...

being widely accepted in today's business as the cornerstone of the success of enterprises that have adopted this business philosophy as the alphabet business. It is enough to look at the Forbes list of the hundred best companies in the world in terms of CSR engagement and also immediately conclude that this is the largest, richest, best organized companies in the global market, whose impact on the world economy is very important. All of the company in its mission statement-a highlight model of corporate social responsibility as its final and strategic commitment. Benevolent or critical, but it should be noted that it is not from a pure innocent love towards the environment, its employees or the communities in which they operate, but because of the well known fact this means profit growth, influence and market share.

The synthesized data in this study show that companies in the countries of Southeast Europe, Bosnia and Herzegovina, Croatia and Serbia shared the same opinion as mentioned corporation from the Forbes list. However, some of them, such as, Microsoft, which is a leader in the abovementioned list, included in this research, in addition to Coca-Cola, Cisco or Avon, and have almost identical habits as well as their sister companies in the markets of Germany, Great Britain or United States of America.

Guided by the maxim that the world is now a global village, the achievements of the most successful global companies that operate in the markets covered by this study are actually already "infected with the virus CSR" and local companies that are aware of the necessity of giving at the same time while you are taking from the market.

Being a socially responsible company, whether you are in New York, Berlin, Belgrade, Sarajevo and Zagreb, means the same, getting on the bright future of the business.

\section{Reference}

Archie,C.B. (1979).wwwrohan.sdsu.edu/faculty/dunnweb/rprnts.pyramidofc

Babić, M., Simić, M., Šunje, A., Puljić, M. (2008.). Corporate management, Principles and Mechanism, Revicon, Sarajevo,5-82.

Bahtijarević-Šiber, Sikavica, P., Pološki Vokić, N. (2008.). Modern management, Školska knjiga, Zagreb,77-92.

Bajšćanski-Agić, V. (2013). Filantrophy, Research, Fondation Mozaik,14.

Blomstrom, R., Davis, K. (1969.). CSR in social responsibility, London,12-54.

Bouen, Howard (1964.). Corporative social responsibilty strategy.

Cramer, J. (2006). Corporate Social Responsibility and Globalisation - An Action Plan for Business, Greenleaf Publishing.

Čatić-Kajtazović, E. (2011). Ekonomski i pravni okvir za implementaciju društvene odgovornosti preduzeća u $\mathrm{BiH}$, Journal of economic and politics of Transition.

Čičić, N.B, Tihi, B.(2008). Marketing, EFSA UNSA, Sarajevo. 
Čibukčić F.: The model for improving the manufacturing process in Serbian...

Čibukčić, F. (2015.). Corporate social responsibility of global and local companies od SI Europe, Belgrade, 180-203, ec.europa.eu/enterprise/policies/sustainablebusiness/corporate-social-responsibility/index en.htm

Heald, M. (2005). The Social Responsibilities of Business: Company and Comm.1900. - 1960., EditoraTransaction Publishers.

Hopkins, M. (2006). What is Corporate Social Responsibility all about?, John Wiley\&Sons, Ltd., Journal of Public Affairs, August-Novembar, 299.

Kakabadse,A. (2007).CSR, Delving Deep,Boston, 167.

Kotler,P., Lee, N. (2005) Corporate Social responsibility, John Willey and sons, Hoboken, NY.

Omazić, M.A. (2007). Social responsibility of Croatian companies, Doctoral work, Zagreb,

Visser, W., Matten, D., Pohl, M., Tolhurst, N. (2010). A-Z Corporate Social Responsibilities, West Sussex, 8-10.

Werther, W.B., Chandler, D.B. (2006). Strategic Corporate Social Responsibility, 5592. 